\title{
Mucormycosis: A Review on Environmental Fungal Spores and Seasonal Variation of Human Disease
}

\author{
Rima I. El-Herte, Tania A. Baban, Souha S. Kanj* \\ Division of Infectious Diseases, Department of Internal Medicine, American University of Beirut Medical Center, Beirut, Lebanon. \\ Email: ${ }^{*}$ sk11@aub.edu.lb
}

Received May $1^{\text {st }}, 2012$; revised June $3^{\text {rd }}, 2012$; accepted July $5^{\text {th }}, 2012$

\begin{abstract}
Mucormycosis is on the rise especially among patients with immunosuppressive conditions. There seems to be more cases seen at the end of summer and towards early autumn. Several studies have attempted to look at the seasonal variations of fungal pathogens in variou indoor and outdoor settings. Only two reports, both from the Middle East, have addressed the relationship of mucormycosis in human disease with climate conditions. In this paper we review, the relationship of indoor and outdoor fungal particulates to the weather conditions and the reported seasonal variation of human cases.
\end{abstract}

Keywords: Mucormycosis; Seasonal Variation; Fungal Air Particulate Concentration; Mucor; Rhizopus; Rhinocerebral

\section{Introduction}

Mucormycosis refers to infections caused by molds belonging to the order of Mucorales. Members of the family Mucoraceae are the most common cause of mucormycosis in humans. This includes the genera Absidia, Mucor, Rhizomucor, and Rhizopus. Two additional pathogenic families are the Cunninghamellaceae and the Saksenaceae. These are opportunistic fungi that are able to cause acute, rapidly progressing fulminant infections in compromised hosts. They can cause rhinocerebral, pulmonary, gastrointestinal, cutaneous and disseminated infections. Risk factors for such infections include diabetes, ketoacidosis, lymphoma, leukemia, neutropenia, corticosteroid use, long term immunosuppressive therapy, deferoxamine therapy, and prior intake of fungal prophylaxis with voriconazole [1]. Such infections are fatal if no adequate and rapid surgical and medical interventions are initiated. Two reports suggested that the incidence of mucormycosis increases in summer and early autumn $[2,3]$. In this review, we present the available published literature on the seasonal variation of the air concentration of various spores of mucorale sp. and other fungi and the seasonal variation of clinical mucormycosis.

\section{Environment and Seasonality}

Mucorales are thermotolerant. They are ubiquitous in nature and widely found on organic substrates, including

${ }^{*}$ Corresponding author. bread, decaying fruits, vegetable matters, crop debris, soil, compost piles, animal excreta, and on excavation and construction sites. Sporangiospores are easily aerosolized, and are readily dispersed throughout the environment making inhalation the major mode of transmission. Published data describing the levels of zygomycete sporangiospores in outdoor and indoor air in relation to seasonal variation is scarce.

\subsection{Outdoor Concentration and Seasonal Variation}

Most of the studies addressing variations of fungal spores in the air in relation to the season have been done in European countries. The earliest study that considered metereological conditions and airborne particulate concentration of fungi was done in Athens and showed that during autumn and winter the number of suspended microfungi was twice as high as in spring and summer [4]; Mucor species were cultured during the months of June through December excluding September. This result suggested a positive correlation with humidity and a negative correlation with temperature. In a Spanish study done in 1980 over a two-year survey on the airborne fungi in the atmosphere of Barcelona, Rhizopus, and $\mathrm{Mu}$ cor were the second most commonly isolated fungi after Aureobasidium [5]. In another study by Herrero in Palencia in 1992, air cultures revealed that Mucor sp. were the most common pathogens (25\%) followed by Aspergillus sp. (23\%) and Penicillium sp. (16\%). Thirty two percent of the fungal colonies grew in autumn, while 
28\% during spring [6]. A study from Ankara, Turkey failed to reveal mucoracae in air particulates but showed a predominance of other fungi such as Cladosporium (75.5\%) followed by Alternaria (6.1\%), Leptosphaeria $(2.2 \%)$ and others. The highest value of spore concentration was detected in July, and the lowest in January. This was thought to be related to monthly mean temperatures, wind velocity and humidity [7]. Soil and air samples from seven different localities around a Turkish city were sampled and revealed that the most isolated genus from air samples was Alternaria (43.96\%), followed by Cladosporium (25.52\%) and Phoma (5.40\%) [8]. Fusarium and Penicillium occurred at very low concentrations in air and no mucoracae were isolated. The highest airborne spore concentration was found during autumn and the lowest concentration during the summer. Aspergillus' air spore concentration was very low in all seasons during the research period [8]. Another Turkish study measuring the indoor and outdoor concentration of fungi in Istanbul revealed that Cladosporium and Alternaria were the most commonly recovered followed by Penicillium, Aspergillus, Rhizopus, Aureobasidium, Mucor and Fusarium at a lower concentration [9]. Oliveria et al. found similar results in Porto, Portugal: Cladosporium being the most common to recover (74.5\%) throughout the year followed by Alternaria, Aspergillus, Penicillium, Botrytis, Coprinus, Epicoccum, Fusarium, Ganoderma, Mucor, and Ustilago. The highest airborne spore concentrations in Porto were observed during summer and late autumn and the lowest during winter and were negatively correlated with wind speed; while positively correlated with temperature and relative humidity. Alternaria, Botrytis and Ganoderma spore density peaked from summer to autumn. Spore densities of Corynespora, Fusarium, Oidium, Periconia and Rhizopus peaked in late spring [10]. Results were similar in studies done from Northeast America where Cladosporium sp. was also dominant in both indoor and outdoor air in summer, with not much isolated mucoracae [11]. In another study done in the USA in 2002, the median outdoor fungal concentrations varied according to seasons and were highest in the fall and summer and lowest in the spring and winter. Mostly they were Cladosporium, Penicillium, Aspergillus; however, there was no available data concerning Mucor and Rhizopus sp. [12]. The seasonal variation of fungal propagules in a fruit market environment in Nagpur, India showed that Aspergillus was the most frequent and predominant genus detected, peaking in summer, followed by Cladosporium, Penicillium and Alternaria peaking during December-January [13]. Fungi related to animals have also been studied. Rodents from a Czech study showed that they harbor various species of Aspergillus, Mucor and Penicillium; R. oryzae represented $10 \%$ of the fungi [14]. Studies on the fungal biota of the fur of dogs in Spain yielded Alternaria, Aspergillus, Cladosporiurn, Chrysosporium, Penicillium and Scopulariopsis. Mucor (27.3\%) peaked in autumn and Rhizopus (14.5\%) in summer [15]. Another study looking into the dermatomycosis of the dogs revealed that Mucor sp. formed $1.5 \%$ of the causative agents mostly in warm and humid climates [16]. In an Indian study, fungi involved in skin infections in poultry included Aspergillus, Pencillium, Alternaria, Rhizopus, Chrysosporium, Mucor, Scopulariopsis among others and the soil tested in the vicinity revealed Chrysosporium, Alternaria, Aspergillus, Paecilomyces, Penicillium, Mucor, and Rhizopus among various other genera [17].

\subsection{Indoor Concentration and Seasonal Variation}

The spore density of different fungi was measured in different districts of Istanbul and the results showed that Penicillium and Aspergillus were the most abundant followed by Rhizopus, Mucor and Fusarium; Rhizopus was found at a lower density outdoors than in indoor air [9]. In the US, the indoor fungal concentrations were founde to be highest in the fall and summer and lowest in the spring and winter. The most commonly recovered fungi were Cladosporium, Penicillium, the nonsporulating fungi and Aspergillus. Mucor and Rhizopus sp. were detected mostly in winter and summer [12]. Also indoor mycobiota varied with the niche. Wooden and paper materials had the highest median concentrations of fungi whereas mineral insulation, ceramic products, and paints and glues had the lowest. The wooden materials harbored Penicillium and yeasts, as well as Cladosporium and Stachybotrys. Ceramic products, paints and glues seemed to favor Acremonium and Aspergillus versicolor [18].

\subsection{Seasonal Variation of Human Disease}

Roden et al. analyzed 929 cases of mucormycosis without shedding light on its seasonal variation [19]. Possible seasonal variation of mucormycosis has been addressed in 2 studies, both from the Middle East. Al-Ajam et al. reported a series of 16 cases of invasive rhinocerebral, cutaneous and pulmonary mucormycosis. He showed that the onset of symptoms clustered at the end of a dry period, which consistently extended from late May to October; i.e. early summer to end of autumn in 12 out of 16 patients with a statistically significant seasonal variation $(p=0.007)$ which coincided with increasing rain levels [2]. However, data is lacking on the mycobiota species and their concentration in Beirut or any other cities in Lebanon. A similar study from Israel analyzing 36 cases of rhinocerebral mucomycosis showed that most of the cases occurred between August and December with a peak incidence in September. In this country, the weather 
is hot and humid from May till September. Rhizopus oryzae was the most commonly isolated organism [3].

Infection with mucorales has also been reported to occur as a consequence of natural disasters such as volcanic eruptions [20] and tsunami $[21,22]$. In some reports, the victims had multiple sites of necrotizing fasciitis due to R. arrhizus, Apophysomyces elegans and others. Analysis of the volcanic mud flow revealed Rhizopus arrhizus, Mucor sp., Trichoderma sp., Penicillium sp., Fusarium sp., Aspergillus niger, Paecylomyces sp. and Candida sp.

Table 1 summarizes the various studies done correlating fungi, air particulate concentration with season and climate.

\section{Discussion}

The various published reports show that Mucor and Rhizopus sp. are not among the most commonly isolated fungi from outdoors environment with highest outdoor concentrations in spring and summer $[13,15]$, whereas indoor concentration of these fungi was highest during winter and spring [13]. Other studies have failed to detect any mucorales by PCR from indoor and outdoor air samples [23]. Hence a clear conclusion cannot be reached.

Sesonal variation of human mucormycosis seems to be plausible. The 2 studies from the Middle East showed that most cases of mucormycosis occurred in late summer, fall and early winter. In Lebanon, the cases clustered between August and December when the weather ranges from hot and dry to wet and cool. In Israel, the weather is very similar to Lebanon and cases also had a similar distribution according to the months of the year (Figure 1). In both studies there was no attempt to identify the source of infection but infection was attributed to airborne transmission from air conditioners. Two patients of the latter study had infection with $R$. oryzae, which was also cultured from the doctor's office. This suggested that improving the ventilation systems may decreases the incidence. Also no unusual precipitations or temperature data were recorded from the Israeli study. It is probable that infestation can build up in earlier months and manifest in August and September. However, in both studies there is no data about the fungal particulate air concentration to correlate them to this type of fungal infection. Other publications about invasive mucormycosis infection did not mention any information about the season when these patients were diagnosed [19]. There remain many unanswered questions that need to be addressed in future studies. Particularly investigating whether the organisms have a true seasonal variation in outdoor and indoor settings and whether this correlates to human diseases. Since both studies addressing seasonal variations of human disease have been done in the Middle East in countries with similar weather and humidity conditions, the results cannot be extrapolated to other regions and countries. It will be of interest to study this in various centers worldwide where there are increasing numbers of immunosuppressed patients at risk for mucormycosis such as oncology and transplant patients. Knowledge about seasonal variation of this deadly fungal infection might have important implications. Physicians will have a lower threshold to consider such infections in their immunocompromised hosts, better attention to air filters in transplant units during peak seasons, and possible prophylaxis in outbreak situations, especially with the availability of potent oral agents such as posaconazole are to be considered [24]. Since mucormycosis is fatal in most cases when therapy is delayed, more efforts should be done by the medical community caring for immunocompromised patients to better understand its epidemicology. The availability of advanced culture and molecu-

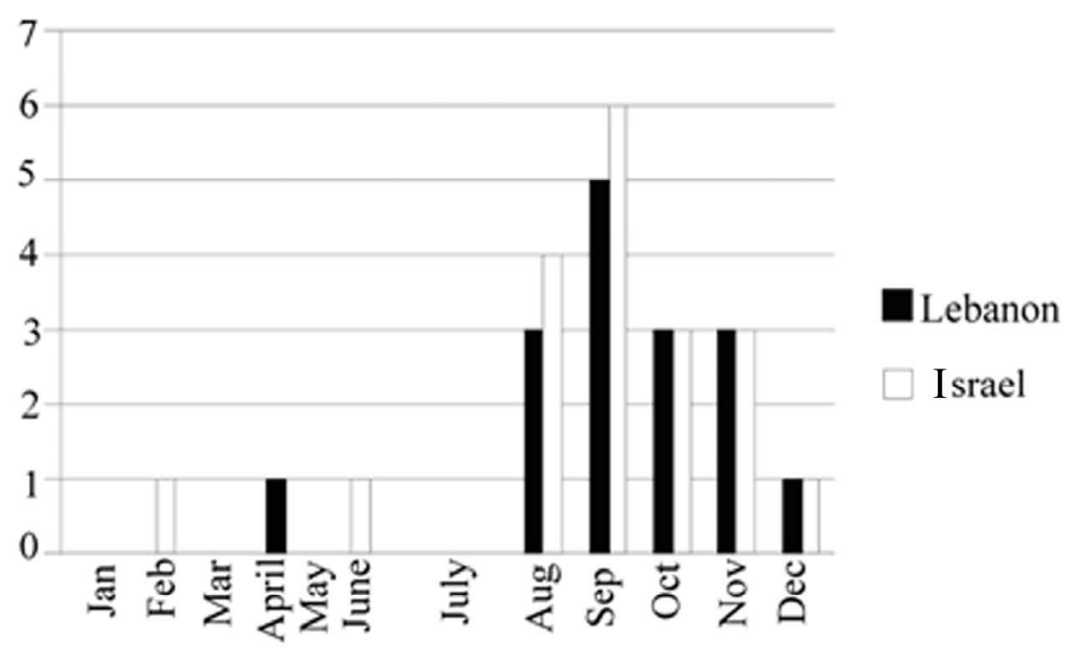

Figure 1. Distribution of mucormycosis cases versus month of year in Israel and Lebanon (with permission from author [2]). 
Table 1. The table shows each author's publication, country, year time during which the highest concentration of fungi was recovered, the fungi recovered and associated meteorological factors. High humidity, rain, low temperatures showed positive correlation with increasing air particulates concentration; not all studies showed correlation with wind velocity.

\begin{tabular}{|c|c|c|c|c|}
\hline & Author/Country & Year Time & Molds Species & Factors \\
\hline \multirow[t]{14}{*}{ Outdoor } & Bartzokas/Greece & Autumn \& Winter & $\begin{array}{l}\text { Aspergillus } \\
\text { Penicillium } \\
\text { Alternaria } \\
\text { Mucor }\end{array}$ & $\begin{array}{l}\text { Low Temperature and } \\
\text { Increase Humidity }\end{array}$ \\
\hline & Calvo et al./Spain & & $\begin{array}{c}\text { Aureobasidium } \\
\text { Rhizopus } \\
\text { Mucor } \\
\text { Arthrinium } \\
\text { Fusarium }\end{array}$ & \\
\hline & Herrero/Spain & Autumn \& Spring & $\begin{array}{c}\text { Mucor } \\
\text { Aspergillus } \\
\text { Penicillium }\end{array}$ & \\
\hline & Ceter et al./Turkey & July & $\begin{array}{l}\text { Cladosporium } \\
\text { Alternaria } \\
\text { Leptosphaeria }\end{array}$ & $\begin{array}{c}\text { Humidity } \\
\text { Temperature } \\
\text { Wind Speed }\end{array}$ \\
\hline & Asan et al./Turkey & Autumn & $\begin{array}{c}\text { Alternaria } \\
\text { Cladosporium } \\
\text { Phoma }\end{array}$ & \\
\hline & Çolakoğlu/Turkey & & $\begin{array}{c}\text { Cladosporium } \\
\text { Alternaria } \\
\text { Penicillius } \\
\text { Aspergillus } \\
\text { Rhizopus } \\
\text { Aureobasidium } \\
\text { Mucor Fusarium }\end{array}$ & \\
\hline & Oliveria et al./Portugal & Summer \& Late Autumn & $\begin{array}{c}\text { Cladosporium } \\
\text { Alternaria, } \\
\text { Aspergillus } \\
\text { Penicillium }\end{array}$ & Temperature Humidity \\
\hline & Ren et al./ & Summer & Cladosporium & \\
\hline & Shelton et al./USA & Summer \& Autumn & $\begin{array}{c}\text { Cladosporium } \\
\text { Penicillium } \\
\text { Aspergillus }\end{array}$ & \\
\hline & Kakde et al./India & December-January/Summer & $\begin{array}{l}\text { Aspergillus } \\
\text { Cladosporiu } \\
\text { Penicillium } \\
\text { Alternaria }\end{array}$ & \\
\hline & Stejskal et al./Czech & & $\begin{array}{l}\text { Aspergillu, } \\
\text { Mucor } \\
\text { Penicillium } \\
\text { R. oryzae }\end{array}$ & \\
\hline & Cabafies et al./Spain & Summer \& Autumn & $\begin{array}{c}\text { Alternaria, } \\
\text { Aspergillus } \\
\text { Cladosporiurn } \\
\text { Chrysosporim } \\
\text { Penicillium } \\
\text { Scopulariopsis } \\
\text { Mucor }\end{array}$ & \\
\hline & Jand et al. & & Mucor & Warmth and Humidity \\
\hline & Saidi et al./India & & $\begin{array}{c}\text { Chrysosporium } \\
\text { Alternaria } \\
\text { Aspergillus } \\
\text { Paecilomyces } \\
\text { Penicillius Mucor } \\
\text { Rhizopus }\end{array}$ & \\
\hline
\end{tabular}




\section{Continued}

\begin{tabular}{|c|c|c|c|c|}
\hline \multirow[t]{2}{*}{ Indoor } & Çolakoğlu/Turkey & & $\begin{array}{c}\text { Penicillium } \\
\text { Aspergillus } \\
\text { Rhizopus, Mucor } \\
\text { Fusarium } \\
\text { Rhizopus }\end{array}$ & \\
\hline & Shelton et al. & $\begin{array}{l}\text { Fall \& Summer } \\
\text { Winter \& Summer }\end{array}$ & $\begin{array}{c}\text { Cladosporium, } \\
\text { Penicillium } \\
\text { Aspergillus } \\
\text { Mucor } \\
\text { Rhizopus sp. }\end{array}$ & \\
\hline Human Disease & $\begin{array}{l}\text { Al-Ajam et al./Lebanon } \\
\text { Shpitzer et al./Israel }\end{array}$ & $\begin{array}{c}\text { May-October/Summer-Autumn } \\
\text { August-December/Summer-Winter }\end{array}$ & & Rain \\
\hline
\end{tabular}

lar techniques would help in correlating environmental fungi to human diseases [25].

\section{REFERENCES}

[1] G. Lamaris, R. Ben-Ami, R. Lewis, G. Chamilos, G. Samonis and D. Kontoyiannis, "Increased virulence of Zygomycetes Organisms Following Exposure to Voriconazole: A Study Involving Fly and Murine Models of Zygomycosis," The Journal of Infectious Diseases, Vol. 199, No. 9, 2009, pp. 1399-1406. doi:10.1086/597615

[2] M. Al-Ajam, A. R. Bizri, J. Mokhbat, J. Weedon and L. Lutwick, "Mucormycosis in the Eastern Mediterranean: A Seasonal Disease," Epidemiology \& Infection, Vol. 134, No. 2, 2006, pp. 341-346. doi:10.1017/S0950268805004930

[3] T. Shpitzer, N. Keller, M. Wolf, A. Goldschmied-Reouven, G. Bahar, I. Bahar, J. Kronenberg, R. Feinmesser and Y. Talmi, " Seasonal Variations in Rhino-Cerebral Mucor Infection," Annals of Otology, Rhinology and Laryngology, Vol. 114, No. 9, 2005, pp. 695-698.

[4] C. Bartzokas, "Relationship between the Metereological Conditions and the Air-Borne Fungal Flora of the Athens Metropolitan Area," Mycopathologia, Vol. 57, No. 1, 1975, pp. 35-38. doi:10.1007/BF00431176

[5] M. Calvo, J. Guarro, G. Suarez and C. Ramírez, "AirBorne Fungi in the Air of Barcelona (Spain). IV. Various Isolated Genera," Mycopathologia, Vol. 71, No. 2, 1980, pp. 119-123. doi:10.1007/BF00440618

[6] B. Herrero, "Weekly Variation of Fungal Colonies in the Atmosphere of Palencia (Spain) Throughout the Year 1992," Journal of Investigational Allergology and Clinical Immunology, Vol. 7, No. 6, 1997, pp. 611-618.

[7] T. Ceter and N. Pinar, "Atmospheric Concentration of Fungus Spores in Ankara and the Effect of Meteorological Factors in 2003 Period," Bulletin of Microbiology, Vol. 43, No. 4, 2009, pp. 627-638.

[8] A. Asan, S. Sarica Okten, and B. Sen, "Airborne and Soilborne Microfungi in the Vicinity Hamitabat Thermic Power Plant in Kirklareli City (Turkey), Their Seasonal Distributions and Relations with Climatological Factors," Environmental Monitoring and Assessment, Vol. 164, No. 1-4, 2010, pp. 221-231. doi:10.1007/s10661-009-0887-8

[9] G. Çolakoğlu, "Indoor and Outdoor Mycoflora in the Dif- ferent Districts of the City of Istanbul (Turkey)," Indoor and Built Environment, Vol. 13, No. 2, 2004, pp. 91-100.

[10] M. Oliveria, H. Ribeiro and I. Abreu," Annual variation of Fungal Spores in Atmosphere of Porto: 2003," Annals of Agricultural and Environmental Medicine, Vol. 12, No. 2, 2005, pp. 309-315.

[11] P. Ren, T. Jankun and B. Leaderer, "Comparisons of Seasonal Fungal Prevalence in Indoor and Outdoor Air and in House Dusts of Dwellings in One Northeast American County," Journal of Exposure Analysis and Environmental Epidemiology, Vol. 9, No. 6, 1999, pp. 560-568. doi:10.1038/sj.jea.7500061

[12] B. Shelton, K. Kirkland, W. Flanders and G. Morris, "Profiles of Airborne Fungi in Buildings and Outdoor Environments in the United States," Applied and Environmental Microbiology, Vol. 68, No. 4, 2002, pp. 1743-1753. doi:10.1128/AEM.68.4.1743-1753.2002

[13] U. Kakde, H. Kakde and A. Saoji, "Seasonal Variation of Fungal Propagules in a Fruit Market Environment, Nagpur (India)," Aerobiologia, Vol. 17, No. 2, 2001, pp. 177 182. doi:10.1023/A:1010849522964

[14] V. Stejskal, J. Hubert, A. Kubatova and M. Vanova, "Fungi Associated with Rodent Feces in Stored Grain Environment in the Czech Republic," Journal of Plant Diseases and Protection, Vol. 112, No. 1, 2005, pp. 98-102.

[15] F. Cabafies, M. Abarca, M. Bragulat and G. Castella, "Seasonal Study of the Fungal Biota of the Fur of Dogs," Mycopathologia, Vol. 133, No. 1, 1996, pp. 1-7. doi:10.1007/BF00437092

[16] S. Jand and M. Gupta," Dermatomycosis in Dogs," Mycoses, Vol. 32, No. 2, 1989, pp. 104-105. doi:10.1111/j.1439-0507.1989.tb02213.x

[17] S. Saidi, P. Das and A. Sikdar," Keratinophilic Fungi of Poultry and Their Environment in India," Journal of Comparative Microbiology, Immunology and Infectious Diseases, Vol. 21, No. 1, 2000, pp. 49-55.

[18] A. Hyvärinen, T. Meklin, A. Vepsäläinen and A. Nevalainen, "Fungi and Actinobacteria in Moisture-Damaged Building Materials - Concentrations and Diversity," International Biodeterioration \& Biodegradation, Vol. 49, No. 1, 2002, pp. 27-37.

[19] M. Roden, T. Zaoutis, W. Buchanan, T. Knudsen, T. Sarkisova, R. Schaufele, M. Sein, T. Sein, C. Chiou, J. Chu, D. Kontoyiannis and T. Walsh, "Epidemiology and Out- 
come of Zygomycosis: A Review of 929 Reported Cases," Clinical Infectious Diseases, Vol. 41, No. 5, 2005, pp. 634653. doi:10.1086/432579

[20] J. Patiño, D. Castro, A. Valencia and P. Morales," Necrotizing Soft Tissue Lesions after a Volcanic Cataclysm," World Journal of Surgery, Vol. 15, No. 2, 1991, pp. 240247. doi:10.1007/BF01659059

[21] B. Snell and K. Tavakoli," Necrotizing Fasciitis Caused by Apophysomyces Elegans Complicating Soft-Tissue and Pelvic Injuries in a Tsunami Survivor from Thailand," Plastic and Reconstructive Surgery, Vol. 119, No. 1, 2007, pp. 448-449. doi:10.1097/01.prs.0000233624.34950.f8

[22] D. Andresen, A. Donaldson, L. Choo, A. Knox, M. Klaassen, C. Ursic, L. Vonthethoff, S. Krilis and P. Konecny, "Multifocal Cutaneous Mucormycosis Complicating Polymicrobial Wound Infections in a Tsunami Survivor from Sri Lanka," Lancet, Vol. 365, No. 9462, 2005, pp. 876-878. doi:10.1016/S0140-6736(05)71046-1
[23] T. Meklin, T. Reponen, C. McKinstry, S. Cho, S. Grinshpun, A. Nevalainen, A. Vepsäläinen, R. Haugland, G. Lemasters and S. Vesper, "Comparison of Mold Concentrations Quantified by MSQPCR in Indoor and Outdoor Air Sampled Simultaneously," Science of the Total Environment, Vol. 382, No. 1, 2007, pp. 130-134. doi:10.1016/j.scitotenv.2007.03.031

[24] E. Spreghini, F. Orlando, D. Giannini and F. Barchiesi, "In Vitro and in Vivo Activities of Posaconazole against Zygomycetes with Various Degrees of Susceptibility," Journal of Antimicrobial Chemotherapy, Vol. 65, No. 10, 2010, pp. 2158-2163. doi:10.1093/jac/dkq276

[25] S. Hammond, R. Bialek, D. Milner, E. Petschnigg, L. Baden and F. Marty," Molecular Methods to Improve Diagnosis and Identification of Mucormycosis," Journal of Clinical Microbiology, Vol. 49, No. 6, 2011, pp. 21512153. doi:10.1128/JCM.00256-11 